Keywords: NGS, $M C U$

Material Compatibility

Retention: Permanent

\title{
Miscibility Evaluation of the Next Generation Solvent with Polymers Currently Used at DWPF, MCU, and Saltstone
}

F. F. Fondeur

April 2013

Savannah River National Laboratory Savannah River Nuclear Solutions, LLC Aiken, SC 29808 contract number DE-AC09-08SR22470. 
SRNL-STI-2013-00014

Revision 0

\section{DISCLAIMER}

This work was prepared under an agreement with and funded by the U.S. Government. Neither the U.S. Government or its employees, nor any of its contractors, subcontractors or their employees, makes any express or implied:

1. warranty or assumes any legal liability for the accuracy, completeness, or for the use or results of such use of any information, product, or process disclosed; or

2. representation that such use or results of such use would not infringe privately owned rights; or

3. endorsement or recommendation of any specifically identified commercial product, process, or service.

Any views and opinions of authors expressed in this work do not necessarily state or reflect those of the United States Government, or its contractors, or subcontractors.

\section{Printed in the United States of America}

Prepared for

U.S. Department of Energy 


\section{REVIEWS AND APPROVALS}

\section{AUTHORS:}

F. F. Fondeur, Separation \& Actinide Science

Date

\section{TECHNICAL REVIEW:}

T. E. Skidmore, Materials NDE \& Consultation

Date

\section{APPROVAL:}

F. M. Pennebaker, Manager

Date

Advanced Characterization \& Processing

S. L. Marra, Manager

Date

Environmental \& Chemical Process Technology Research Programs

E. A. Brass, Project Engineering Manager

Date NGS Implementation Project 


\section{EXECUTIVE SUMMARY}

The Office of Waste Processing, within the Office of Technology Innovation and Development, funded the development of an enhanced Caustic-Side Solvent Extraction (CSSX) solvent for deployment at the Savannah River Site for removal of cesium from High Level Waste. This effort lead to the development of the Next Generation Solvent (NGS) with Tris(3,7-dimethyl octyl) guanidine (TiDG). The first deployment target for the NGS solvent is within the Modular CSSX Unit (MCU). Deployment of a new chemical within an existing facility requires verification that the new chemical components are compatible with the installed equipment. In the instance of a new organic solvent, the primary focus is on compatibility of the solvent with organic polymers used in the affected facility. This report provides the calculated data from exposing these polymers to the Next Generation Solvent.

An assessment of the dimensional stability of polymers known to be used or present in the MCU, Defense Waste Processing Facility (DWPF), and Saltstone facilities that will be exposed to the NGS showed that TiDG could selectively affect the elastomers and some thermoplastics to varying extents, but the typical use of these polymers in a confined geometry will likely prevent the NGS from impacting component performance. The polymers identified as of primary concern include Grafoil $^{\circledR}$ (flexible graphite), Tefzel ${ }^{\circledR}$, Isolast ${ }^{\circledR}$, ethylene-propylene-diene monomer (EPDM) rubber, nitrile-butadiene rubber (NBR), styrene-butadiene rubber (SBR), ultra high molecular weight polyethylene (UHMWPE), and fluorocarbon rubber (FKM). Certain polymers like NBR and EPDM were found to interact mildly with NGS but their calculated swelling and the confined geometry will impede interaction with NGS. In addition, it was found that Vellumoid (cellulose fibers-reinforced glycerin and protein) may leach protein and Polyvinyl Chloride (PVC) may leach plasticizer (such as Bis-Ethylhexyl-Phthalates) into the NGS solvent. Either case will not impact decontamination or immobilization operations at Savannah River Site (SRS). Some applications have zero tolerance for dimensional changes such as the operation of valves while other applications a finite dimensional change improves the function of the application such as seals and gaskets. Additional considerations are required before using the conclusions from this work to judge outcomes in field applications.

Decane, a component of Isopar ${ }^{\circledR} L$ that is most likely to interact with the polymers, mildly interacted with the elastomers and the propylene based polymers but their degree of swelling is at most $10 \%$ and the confined geometry that they are typically placed in indicate this is not significant. In addition, it was found that Vellumoid may leach protein into the NGS solvent. Since Vellumoid is used at the mixer in Saltstone where it sees minimum quantities of solvent, this leaching has no effect on the extraction process at MCU or the immobilization process at saltstone.

No significant interaction is expected between MaxCalix and the polymers and elastomers used at MCU, DWPF, and Saltstone. Overall, minimal and insignificant interactions are expected on extraction and immobilization operations when MCU switches from CSSX to NGS solvent.

It is expected that contacting NGS will not accelerate the aging rate of polymers and elastomers under radiation and heat. This is due to the minimal interaction between NGS and the polymers and the confined geometries for these polymers.

SRNL recommends the use of the HSP method (for screening) and some testing to evaluate the impact of other organic such as alcohols, glycolate, and their byproducts on the polymers used throughout the site. 


\section{TABLE OF CONTENTS}

LIST OF TABLES




\section{LIST OF TABLES}

Table 2-1. A list of the polymers used in MCU selected for testing ............................................ 2

Table 2-2. Example Technical Report Table Caption ....................................................................2

Table 2-3. A list and structure of the components that make up CSSX and the improved solvent..3

Table 2-4. The solubility parameters of the polymers used at DWPF and Saltstone and other thermoplastic polymers for comparison .......................................................................

Table 2-5. The solubility parameters of the selected suppressor selected .......................................4

\section{LIST OF FIGURES}

Figure 2-1. Three dimensional view of the solubility parameters............................................... 5

Figure 3-1. The effect of TOA on typical polymers currently used at MCU, DWPF, and Saltstone.

Figure 3-2. The miscibility of LIX $® 79$ in polymers currently used at DWPF, MCU, and Saltstone

Figure 3-3. The miscibility of TiDG in polymers currently used at MCU, DWPF, and Saltstone

Figure 3-4. The percent of maximum swelling that polymer will experience in contact with the suppressors

Figure 3-5. The Relative Energy Difference between a TOA-TiDG mixture and the polymers and rubbers examined in this work ....................................................................... 10

Figure 3-6. An schematic of Kevlar ${ }^{\circledR}$ aromatic polyamide chemical structure

Figure 3-7. The Relative Energy Difference (RED) between MaxCalix and the polymers and rubbers under consideration

Figure 3-8. The Relative Energy Difference (RED) between Isopar ${ }^{\circ} L$ and the polymers under consideration.

Figure 3-9. The percent of maximum swelling expected for these polymers in contact with dodecane 


\section{LIST OF ABBREVIATIONS}

$\begin{array}{ll}\text { CPVC } & \text { Surface Chlorinated PVC } \\ \text { CSSX } & \text { Caustic-Side Solvent Extraction } \\ \text { DiDG } & \text { N,N'-Dicyclohexyl-N”-isotridecylguanidine } \\ \text { DWPF } & \text { Defense Waste Processing Facility } \\ \text { EP } & \text { Ethylene-Propylene polymer } \\ \text { EPDM } & \text { Ethylene-Propylene-Diene Monomer Rubber } \\ \text { FKM } & \text { Fluorocarbon rubber } \\ \text { Grafoil } & \text { Graphite sheet } \\ \text { HDPE } & \text { High Density Polyethylene } \\ \text { HSP } & \text { Hansen's Solubility Parameters } \\ \text { Isolast } & { }^{\circledR} \\ \text { Kevlar } & \text { FFKM rubber } \\ \text { MCU } & \text { Aromatic polyamide } \\ \text { NBR } & \text { Modular CSSX Unit } \\ \text { NGS } & \text { Nitrile-butadiene rubber } \\ \text { NR } & \text { Next Generation Solvent } \\ \text { ORNL } & \text { Natural Rubber } \\ \text { PP } & \text { Oak Ridge National Laboratory } \\ \text { PPS } & \text { Polypropylene } \\ \text { PVC } & \text { Polyphenylene Sulfide } \\ \text { PVDF } & \text { Polyvinyl Chloride } \\ \text { PTFE } & \text { Polyvinylidene fluoride } \\ \text { PTFE-CR } & \text { Polytetrafluoroethylene } \\ \text { PS } & \text { Corona Resistance PTFE } \\ \text { RED } & \text { Polystyrene } \\ \text { SBR } & \text { Relative Energy Difference } \\ \text { SHT } & \text { Styrene-butadiene rubber } \\ \text { SRNL } & \text { Solvent Hold Tank } \\ \text { SRS } & \text { Savannah River National Laboratory } \\ \text { Tefzel } & \text { Savannah River Site } \\ \text { TOA } & \text { Ethylene-tetrafluoroethylene }{ }^{\circledR} \text { (ETFE) copolymer } \\ \text { TiDG } & \text { Trioctylamine } \\ \text { UHMWPE } & \text { Tris(3,7-dimethyl octyl guanidine HCl) } \\ & \text { Ultra high molecular weight polyethylene } \\ & \end{array}$




\subsection{Introduction}

The MCU has processed more than two million gallons of supernate waste since 2008. ${ }^{1}$ Operations have proven successful thanks to the resilience, reliability, and repeatable performance of the CSSX process. Researchers at the Oak Ridge National Laboratory (ORNL), Savannah River National Laboratory (SRNL), and Argonne National Laboratory have been developing a NGS (or "improved solvent") and stripping solution that improves both cesium extraction from supernate and stripping from the current solvent. The development took into consideration lessons learned from years of MCU operation.

In 2010, laboratory scale testing of the NGS demonstrated excellent achievement of performance goals. $^{2,3}$ Those encouraging results are the basis for larger scale tests currently being conducted at SRNL. Performance verification tests examined mass transfer, hydraulic behavior (such as pumping, phase disengagement, phase carryover), and solvent coalescing. The results from the scale-up test will aid in validating the laboratory scale results as a forecaster for final deployment of the NGS at MCU or the Salt Waste Processing Facility.

To fully implement the NGS at the MCU, additional knowledge is needed on the chemical and physical compatibility of the NGS with the non-metallic components currently used in the MCU and related downstream facilities. These non-metallic components serve a crucial role in sealing and isolating the solvent and solutions from the environment while allowing the flexibility for removing, replacing, and maintaining the different metallic components such as valves and flanges at MCU. When the existing solvent is replaced with the NGS in the MCU process, existing non-metallic components will experience a slightly different chemical environment that could lead to a shorter lifetime (possible leaks or binding due to swelling) or duty cycle, or absorption of a key component like the extractant MaxCalix ${ }^{\Sigma}$.

For instance, amines are known to degrade the performance of certain polymers (for example polycarbonate swells with liquid amines) and the new suppressor in the NGS, a derivative of guanidine (TiDG), may be more reactive in this regard than the trioctylamine (TOA) in the current CSSX solvent formulation. $^{\Re}$ To understand if the chemistry change will affect the non-metallic components (and to what extent) in MCU, DWPF, and Saltstone facilities, this report used Hansen's correlations for solubility of organic liquids into polymer to make a comparative determination. This is a well-documented method for evaluating the potential for interaction between an organic liquid and a polymer surface. ${ }^{4}$ A previous report on compatibility issues with polymers used at MCU did not include the polymers used in DWPF or Saltstone. ${ }^{5}$ Therefore, SRNL was requested to evaluate the impacts via HLE-TTR-2012-010 Revision 1. The effort is described in SRNL-RP-2012-00842, "TTQAP for Cesium Mass Transfer Test w/ NGS \& Miscellaneous White Papers”.

\subsection{Experimental}

A previous report investigated the miscibility of the polymers currently used at MCU with NGS-DCiDG. ${ }^{6}$ Those polymers are listed in Table 2-1. DCiDG contains the guanidine molecular group and it serves as a baseline comparison for TiDG. The polymers investigated in this report are listed in Table 2-2 and Appendix A. The extraction solvent composition used in the contact test is listed in Table 2-3. Fillers, activators, accelerators, ozone protectors, inhibitors, and other ingredients commonly used with rubbers and polymers are listed in Appendix B. These are not necessarily inclusive of the ingredients used in any of the specific polymers used in SRS facilities.

\footnotetext{
$\Sigma^{\Sigma}$ The extractant, MaxCalix, stands for 1,3-alt-25,27-Bis(3,7-dimethyloctyloxy)calix[4]arenebenzocrown-6

${ }^{\Re}$ The suppressor is a derivitized guanidine, N, N'-cyclohexyl, N',-isotridecyl guanidine.
} 
Table 2-1. A list of the polymers used in MCU selected for testing.

\begin{tabular}{|c|c|c|}
\hline Polymer Name & $\begin{array}{c}\text { Chemical Formula of repeat } \\
\text { unit }\end{array}$ & Shape or Form \\
\hline 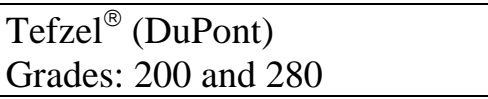 & $\begin{array}{c}-\left(\mathrm{CF}_{2}-\mathrm{CF}\right)-\left(\mathrm{CH}_{2}-\mathrm{CF}_{2}\right)-\left(\mathrm{CF}_{2}-\mathrm{CF}_{1}\right)-\left(\mathrm{CH}_{2}-\mathrm{CH}_{2}\right)- \\
\mathrm{CF}_{3}\end{array}$ & Sheet and Gasket \\
\hline $\begin{array}{l}\text { Isolast }^{\circledR} \quad \text { (carbon filled). } \\
\text { Possible PFR } 40 \text { or similar }\end{array}$ & 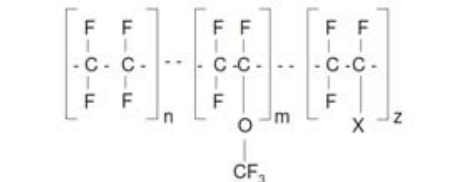 & O-ring \\
\hline $\begin{array}{l}\text { Grafoil }^{\circledR} \text { (GrafTech } \\
\text { International) }\end{array}$ & $\begin{array}{c}\text { Particles of } \mathrm{C}_{6}(\mathrm{SP} 2 \\
\text { hybridized) pressed together }\end{array}$ & Sheet \\
\hline $\begin{array}{l}\text { Carbon-filled PEEK (30 wt \% } \\
\text { carbon filled) }\end{array}$ & & Molded Piece \\
\hline PVC & {$\left[\begin{array}{ll}\mathrm{H} & \mathrm{H}\end{array}\right]_{\mathrm{n}}$} & Pipe \\
\hline
\end{tabular}

Table 2-2. List of typical polymers used at DWPF and Saltstone.

(Several materials are likely used in both facilities to some extent).

\begin{tabular}{||l|c||}
\hline \multicolumn{1}{|c|}{ Polymer or Material } & Location \\
\hline NBR Inorganic fiber & Saltstone \\
\hline NBR Bonded Aramid fibers & Saltstone \\
\hline Grade T Nitrile & Saltstone \\
\hline EPDM/Aramid Fiber & Saltstone \\
\hline Graphite (same as Grafoil ${ }^{\circledR}$ ) & Saltstone, \\
DWPF \\
\hline EPDM & Saltstone, \\
& DWPF \\
\hline Vellumoid (cellulose fibers +glycerin+ & Saltstone, \\
protein glue) & DWPF \\
\hline PTFE & Saltstone \\
\hline SBR/Synthetic Fiber & Saltstone \\
\hline Polystyrene & Saltstone \\
\hline Polypropylene sheets & Saltstone \\
\hline Viton A O-rings & DWPF \\
\hline Ultra High Molecular Weight & DWPF, \\
Polyethylene (UHMWPE) & Saltstone \\
\hline Tefzel ${ }^{\circledR E T F E ~}$ & DWPF \\
\hline Lexan used in electrical jumpers & DWPF \\
\hline
\end{tabular}


Table 2-3. A list and structure of the components that make up CSSX, NGS-LIX®79, and NGSTiDG.

\begin{tabular}{|c|c|c|c|}
\hline Component & CSSX & NGS- LIX ${ }^{\circledR} 79$ & NGS-TiDG \\
\hline BOBCalixC6 & & $0 \mathrm{wt} \%$ & $0 \mathrm{wt} \%$ \\
\hline Modifier & 29 wt 0 & $21 \mathrm{wt} \%$ & $21 \mathrm{wt} \%$ \\
\hline Isopar $^{\circledR} \mathrm{L}$ & $\begin{array}{c}\text { Linear/branched C12 } \\
69 \mathrm{wt} \%\end{array}$ & $\begin{array}{c}\text { Linear/branched C12 } \\
74 \mathrm{wt} \%\end{array}$ & $\begin{array}{c}\text { Linear/branched } \\
\text { C12 } \\
74 \text { wt } \%\end{array}$ \\
\hline MaxCalix & $0 \mathrm{wt} \%$ & $50 \mathrm{mM}$ & $50 \mathrm{mM}$ \\
\hline Suppressor & $\begin{array}{l}\text { TOA } \\
1 \mathrm{mM}\end{array}$ & LIX $^{\circledR} 7910 \mathrm{mM}$ & TiDG $3 \mathrm{mM}$ \\
\hline
\end{tabular}

When contacting a multicomponent liquid with a polymer, the general observation is that one or two components penetrate the polymer if there is positive interaction. Positive interaction (mixing, blending, and swelling) is usually observed when "like contacts like." Similarly, when a liquid contacts a multicomponent polymer, the low molecular weight component of the polymer may leach if there is positive interaction with the solvent. Since it is very difficult to speak of molecules of similar chemistry interacting or attracting each other in quantifiable way, a correlation method, Hansen's correlation method, was used to quantify the interaction between molecules.

The Hansen's correlation method ${ }^{7}$ takes the Hilderbrand's solubility parameter (obtained from the cohesive energy or enthalpy of vaporization) and breaks it down into three components that include dispersion (to account for the dispersion force of a molecule or $\delta_{\mathrm{d}}$ ), dipole (to account for polarity or $\delta_{\mathrm{p}}$ ), and hydrogen bonding (or $\delta_{\mathrm{H}}$ ). These three components have been calculated from experimental data and the parameters are available for computing interactions between materials. These Hansen solubility parameters (HSPs) are shown in Table 2-4. In Table 2-4, the parameter "radius" stands for the value that determines if the solubility difference between a polymer and a solvent is significant (attractive). For a mixture of components (either a blend or a compound formulation), the solubility due to dispersion is given by the sum of the volume fraction weighted solubility of each component due to dispersion as shown in Equation 1.

$$
\delta_{\text {mixture }}^{\text {dispersion }}=\frac{\sum_{i} \emptyset_{i} \times \delta_{i}^{\text {dispersion }}}{\sum_{i} \emptyset_{i}}
$$

Equation 1 
In Eq. $1, \phi_{i}$ stand for the volume fraction of the $\mathrm{i}^{\text {th }}$ component and $\delta_{\mathrm{i}}^{\text {dispersion }}$ (the same as $\delta_{\mathrm{d}}$ ) stands for the dispersion of each component. A similar calculation is performed for the dipole and hydrogen bonding (electron transfer) solubility component of a mixture.

When these parameters are not available as in the case of the suppressors considered here, there is a "group contribution" theory ${ }^{8}$ that counts the contribution from each molecular group in a new molecule. This was done for the three suppressors evaluated in this report. Their calculated solubility parameters are shown in Table 2-5.

Table 2-4. The solubility parameters $\left(\delta_{\mathrm{i}}\right)$ of the polymers used at DWPF, Saltstone, and other polymers for comparison. All units are given in $\mathrm{MPa}^{1 / 2}$.

\begin{tabular}{|l|c|c|c|c|c|}
\hline Polymer & Dispersion & Polar & $\begin{array}{l}\text { Hydrogen } \\
\text { Bonding }\end{array}$ & Radius & Solubility \\
\hline Teflon & 17.1 & 8.1 & 1.3 & 4.7 & 18.97 \\
\hline NR 4hrs & 19 & 12.6 & 3.8 & 13.3 & 23.11 \\
\hline BR 4hrs & 17.6 & 2.1 & 2.1 & 7 & 17.85 \\
\hline SBR & 17.2 & 6 & 4.6 & 9.8 & 18.79 \\
\hline NBR & 19.8 & 17.8 & 3.2 & 19 & 26.82 \\
\hline FKM (Viton $\left.{ }^{\circledR}\right)$ & 11.6 & 23 & 5 & 21.6 & 26.24 \\
\hline EPDM & 18.6 & -3.4 & 4.4 & 10.7 & 19.41 \\
\hline PVC & 17.6 & 7.8 & 3.4 & 8.2 & 19.55 \\
\hline Ethylene-Propylene & 16.6 & 0 & 5.2 & 9.1 & 17.40 \\
\hline Natural Rubber & 16 & 4 & 6 & 1.3 & 17.55 \\
\hline HDPE & 18 & 0 & 2 & 2 & 18.11 \\
\hline PTFE L80 CR & 16.2 & 1.8 & 3.4 & 3.9 & 16.65 \\
\hline Kevlar ${ }^{\circledR}$ & 18.32 & 16.10 & 7.91 & 2 & 25.64 \\
\hline ClPVC $^{\text {PlP }}$ & 17.50 & 6.50 & 5.50 & 6.30 & 19.46 \\
\hline PMMA & 17.50 & 5.50 & 3.80 & 4.50 & 18.73 \\
\hline PS & 18.50 & 4.50 & 2.90 & 5.30 & 19.26 \\
\hline PP & 18.00 & 0.00 & 1.00 & 6.00 & 18.03 \\
\hline PPS* & 18.80 & 4.80 & 6.80 & 2.80 & 20.56 \\
\hline PVDF* & 17 & 12.1 & 10.2 & 4.1 & 23.23 \\
\hline
\end{tabular}

*Polymer used for reference.

Table 2-5. The solubility parameters $\left(\delta_{\mathrm{i}}\right)$ of the suppressor selected (units in $\mathrm{MPa}^{1 / 2}$ )

\begin{tabular}{|l|c|c|c|c|c|}
\hline Solvent & Dispersion & Dipole & Hydrogen & Solubility & $\begin{array}{c}\text { Molar } \\
\text { Volumec } \\
\mathbf{m}^{3} / \mathbf{m o l}\end{array}$ \\
\hline TiDG & 17.27 & 1.79 & 4.71 & 17.99 & 504.9 \\
\hline LIX $^{\circledR} 79$ & 17.86 & 2.32 & 5.36 & 18.79 & 390.2 \\
\hline TOA & 15.99 & 1.84 & 3.39 & 16.45 & 434.7 \\
\hline
\end{tabular}

The miscibility between an organic liquid and a polymer was calculated using Eq. 2. The distance or difference between the solubility parameters for each polymer (listed in Table 2-4) and from the suppressors (listed in Table 2-5) was calculated. 
SRNL-STI-2013-00014

Revision 0

$$
(\mathrm{Ra})^{2}=4\left(\delta_{\mathrm{D} 2}-\delta_{\mathrm{D} 1}\right)^{2}+\left(\delta_{\mathrm{P} 2}-\delta_{\mathrm{P} 1}\right)^{2}+\left(\delta_{\mathrm{H} 2}-\delta_{\mathrm{H} 1}\right)^{2}
$$

Equation 2

Equation 2 is basically the distance between the solubility vectors of the polymer and suppressor as shown in Fig. 2-1.

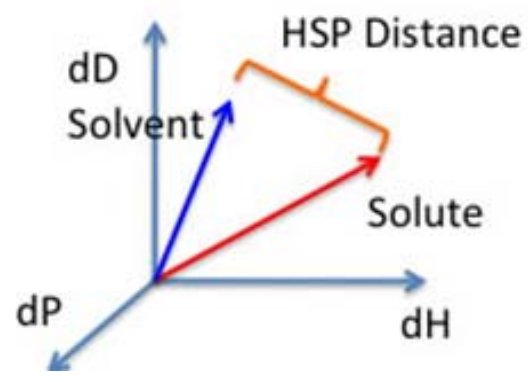

Figure 2-1. Three dimensional view of the solubility parameters.

The ratio between the "Ra" number (defined in Eq. 2) and the "interaction radius" listed in Table 2-4 gives an indication of the interaction strength between the solvent (suppressor) and a given polymer. When this ratio is less than one, the polymer and the suppressor are considered miscible. When this ratio is greater than one, they are immiscible.

The degree of polymer swelling with a given solvent (a measure of miscibility) was determined using the empirical observation that swelling follows a Gaussian function around the solubility parameters of the solvent that interacts with the polymer.

swell $=$ swell $_{\text {maximum }} \times e^{-\left(V_{\text {solvent }} \times \frac{\left(\delta_{\text {solvent }-} \delta_{\text {polymer }}\right)^{2}}{R T}\right)}$

Equation 3

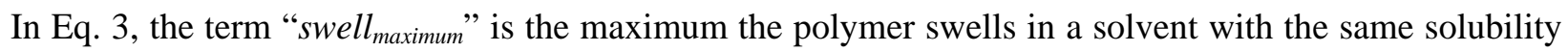
parameters as the polymer and $V_{\text {solvent }}$ stands for the solvent's molar volume.

For a rubber material, the Flory-Renner equation as shown in Equation 4 was used to compute equilibrium swelling.

$0=\left[\operatorname{Ln}\left(1-\phi_{\text {rubber }}\right)+\phi_{\text {rubber }}+\chi \times \phi_{\text {rubber }}^{2}\right]+\phi_{\text {rubber }} \times \frac{\rho}{M w_{\text {crosslinks }}} \times \phi_{\text {rubber }}^{1 / 3}$ Equation 4

In Eq. 4, $\phi_{\text {rubber }}$ stands for the volume fraction of rubber in a rubber swollen with solvent, $\rho$ stands for the density (in gmole $/ \mathrm{cm}^{3}$ ) of the rubber, $\mathrm{Mw}_{\text {crosslinks }}$ stands for the average molecular weight between crosslinks (usually varies from 4,000 to $10,000 \mathrm{gmole} / \mathrm{cm}^{3}$ ), and $\chi$ stands for the Flory-Huggins interaction coefficient [given as $\left(\delta_{\text {solvent }}-\delta_{\text {rubber }}\right)^{2} * \mathrm{~V}_{\text {solvent }} / \mathrm{RT}+0.38$ ].

Some polymers such as Teflon PTFE or UHMWPE are typically very "pure" with little to no additives present. However, many commercial polymers are often composed of several ingredients that include fillers, pigments, plasticizers, anti-wetting agents, antioxidant, fire suppressors and other additives (see Appendix B). Some of these may have leached from the surface of polymers deployed at SRS due to aging and radiation exposure. Inorganic fillers are expected to be resistant to the current CSSX and NGS solvents but their interphase with a polymer may provide a pathway for the current CSSX and NGS 
solvent to permeate inside polymers, rubbers, and thermosets. Thus, the chemical interaction between homopolymers, copolymers, and terpolymers with NGS needs further examination since polymers that have similar dispersion, dipolar, and hydrogen bonding forces as NGS may absorb it.

\subsection{Results and Discussion}

\section{Suppressors}

A recent report ${ }^{5}$ evaluated the miscibility between polymers used at MCU and the NGS-LIX $® 79$ with the current CSSX solvent as a baseline. Dimensional measurements showed that polymers such as PEEK, Grafoil $^{\circledR}$, Tefzel ${ }^{\circledR}$ and Isolast ${ }^{\circledR}$ were not significantly affected by contacting the improved solvent (containing LIX $\circledast 79$ and MaxCalix) and that the observed changes were statistically consistent with similar changes observed with CSSX solvent. In that study PVC leached bis-hexylethyl phthalate into both solvents (NGS-LIX ${ }^{\circledR} 79$ and CSSX) and it was recommended to avoid contact with PVC. The same effect is expected to occur when NGS contacts PVC. No leaching was observed, however, when the improved solvent contacted CPVC (surface chlorinated PVC). Therefore, there should be no plasticizer leaching from CPVC when it contacts NGS. Of the components that make up the organic solvent, the suppressor with its relatively low molecular weight (relative to the other solvent components) and polarity is the most likely to interact, permeate, and swell the engineering polymers used at DWPF and Saltstone. The solubility parameter of LIX®79 (16.93) is similar to that of TiDG (18.79). Therefore, TiDG should have negligible interaction with the polymers used at MCU. The question relates to TiDG interaction with the polymers used at DWPF and Saltstone.

Using HSP for the polymers listed in Table 2-3 (and other polymers for comparison) and the calculated solubility parameters for the suppressors, an immiscibility index was calculated between these groups. The results of that miscibility calculation are shown in Figure 3-1 for TOA, Figure 3-2 for LIX $® 79$, and Figure 3-3 for TiDG. A key to reading these figures is that any $y$-value larger than one $(>1)$ is an indication that the polymer is not miscible with that suppressor. Y-values below 1 indicate miscibility and potential interaction.

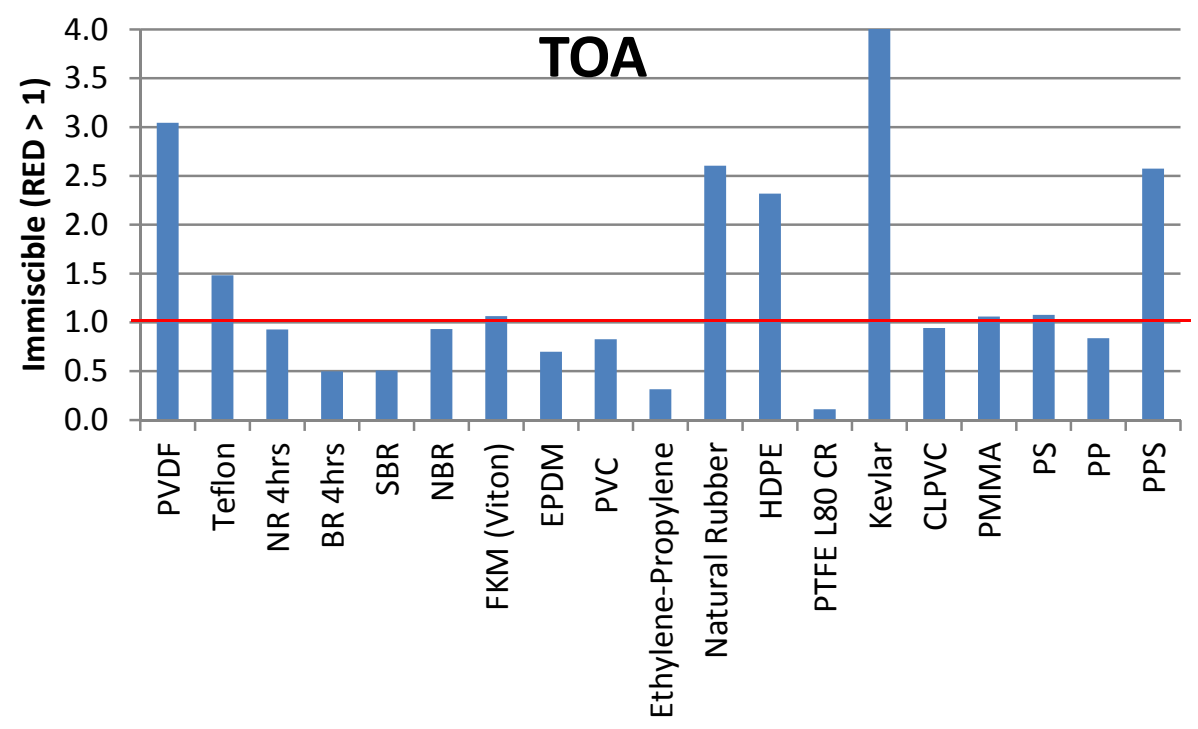

Figure 3-1. The effect of TOA on typical polymers currently used at MCU, DWPF, and Saltstone. 


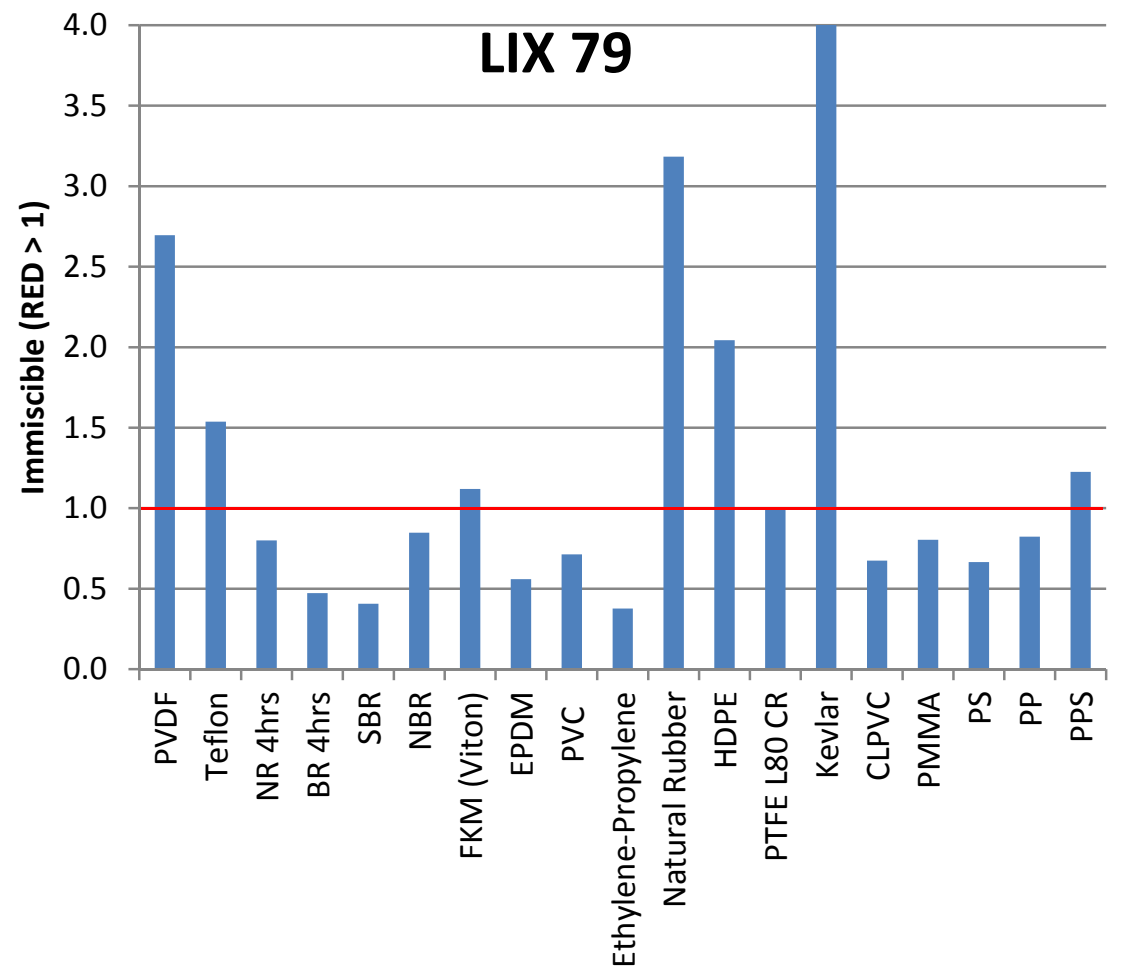

Figure 3-2. The miscibility of LIX ${ }^{\circledR} 79$ in polymers currently used at DWPF, MCU, and Saltstone.

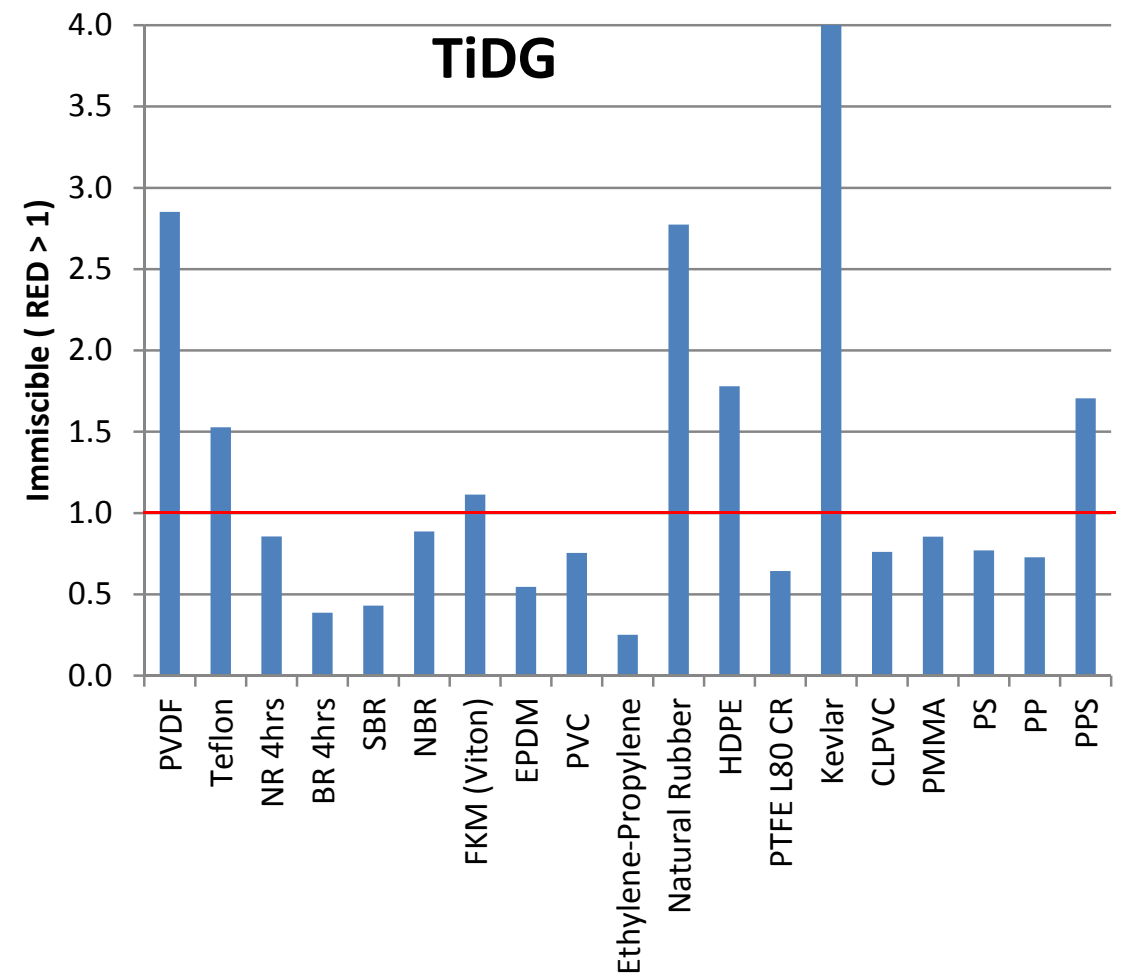

Figure 3-3. The miscibility of TiDG in polymers currently used at MCU, DWPF, and Saltstone. 
Looking at Fig. 3-1, the miscibility index $($ RED $<1)$ indicates that TOA may interact with EP, SBR, BR, EPDM, PVC, and PP. The interaction is expected to be the strongest with EP copolymer. There are likely fewer EP (or EPR) components in the facilities than EPDM as EPDM is more commonly used in sealing applications. The large dispersion force and the smaller hydrogen bonding force in TOA enable it to interact with rubbers and some thermosets. This finding is consistent with data published of some of these polymers in Ref. 6 where some swelling was observed but if the swelling has occurred in service, material performance has not been impacted in the four years that MCU has been operating since 2008 where no report of polymer degradation has been made (except for some valve seat problems with the Isolok samplers containing molded UHMWPE seat). A certain degree of swelling or surface modification is generally tolerable in many polymer applications particularly in static configurations.

A similar set of polymers are also expected to interact with LIX ${ }^{8} 79$. When looking at Fig. 3-2, the same set of polymers that interacted with TOA is also expected to interact with LIX ${ }^{\circ} 79$ in addition to PS and PMMA. This is driven by the more polar nature of LIX ${ }^{\circledR} 79$ despite being larger than TOA. The solubility parameter of LIX®79 (18.79) is similar to that of TOA (16.45). Therefore, both suppressors should have similar interaction with the polymers.

A similar conclusion is reached when viewing the data in Figure 3-3. SBR and EPDM will interact with the suppressor TiDG. The suppressor TiDG has a similar solubility as LIX®79. Thus, a similar interaction with the same set of polymers observed with LIX ${ }^{\circledR} 79$ is expected.

Given the interaction between the suppressors and some of the elastomer and thermoplastics, the next step is to estimate the degree of swelling that may occur when the suppressor contact these polymers.

Figure 3-4 shows the percent swelling from the maximum swelling a polymer can attain in a given solvent. In this figure, the suppressors are treated as solvent relative to the polymers. As can be seen from Fig. 3-4, it appears that rubbers like BR, SBR, and NR swelled up to $20 \%$ of their maximum swelling regardless of the solvent. Similarly, polymers like PS, PP, PPS, HDPE, and EP swelled moderately $(<35 \%)$ relative to their maximum swelling. Overall, if these polymers are physically constrained, this will limit the amount of polymer exposed, thus minimizing the impact.

A relatively strong attractive interaction is predicted between PTFE CR L80 and TOA. PTFE CR is an specially treated PTFE containing additive that increases the wetting between PTFE and the material piece (tube or electrical cord) that it encases. The PTFE contains a small amount of dispersed additive that under ion impact from a corona discharge the additive melt (does not decompose) and provides a film over the surface of PTFE that it is being ion bombarded. The additive gives PTFE CR a self-healing capability. This calculation indicates that TOA can possibly leach out this additive since there is no interaction with PTFE itself. Expect the low molecular weight components of Isopar $\circledast \mathrm{L}$ to attractively interact with PTFE CR. Please note the polymer is used as cable insulation and it is not expected to contact solvent at MCU. 


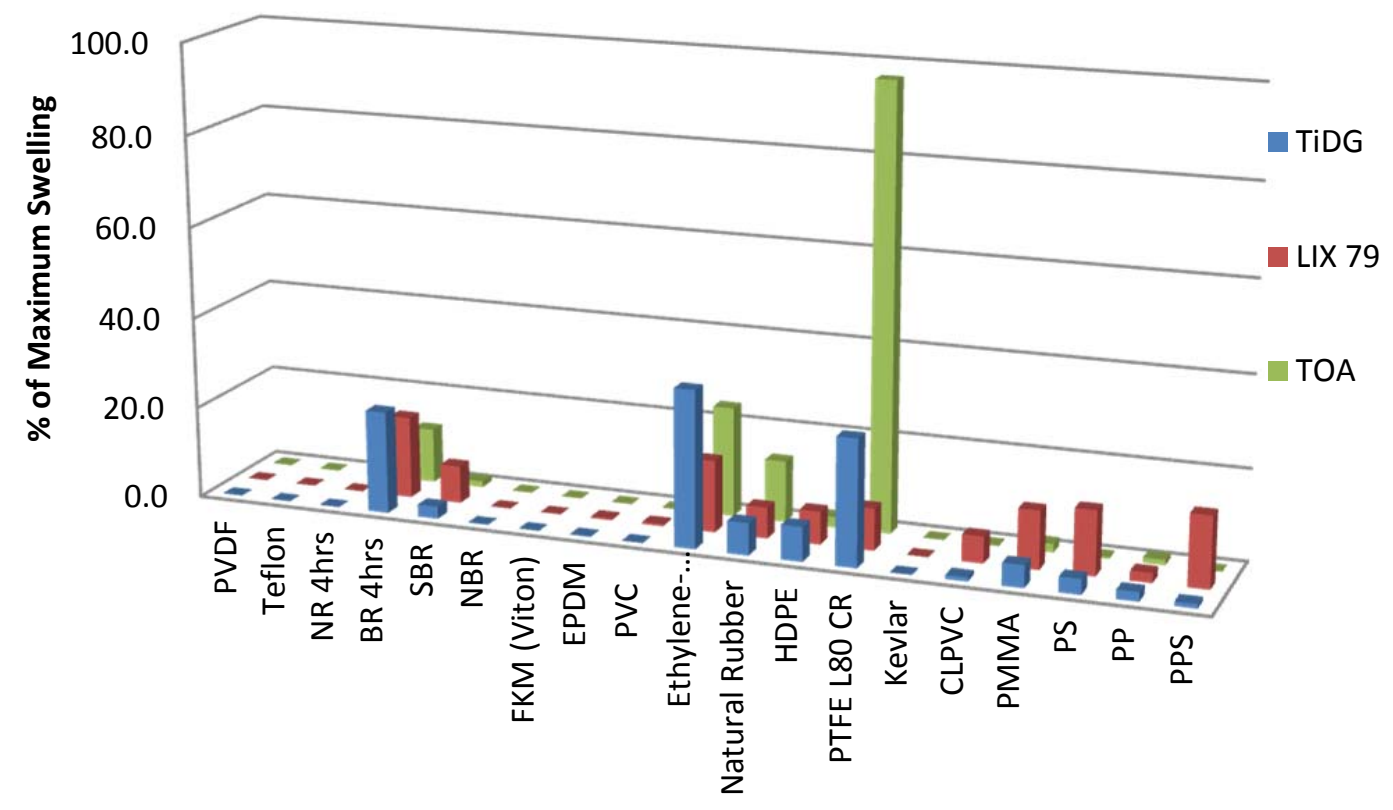

Figure 3-4. The percent of maximum swelling that polymer will experience in contact with the suppressors.

During NGS deployment, some of the current CSSX solvent remaining in the Solvent Hold Tank (SHT) will mix with the NGS resulting in a TOA-TiDG mixture. The impact of a suppressor mixture on polymers and rubbers is bounded by the impact of each suppressor. As shown in Fig. 3-5, the RED values for different ratios of TiDG to TOA mixtures are bounded by the RED values of TiDG and TOA. 


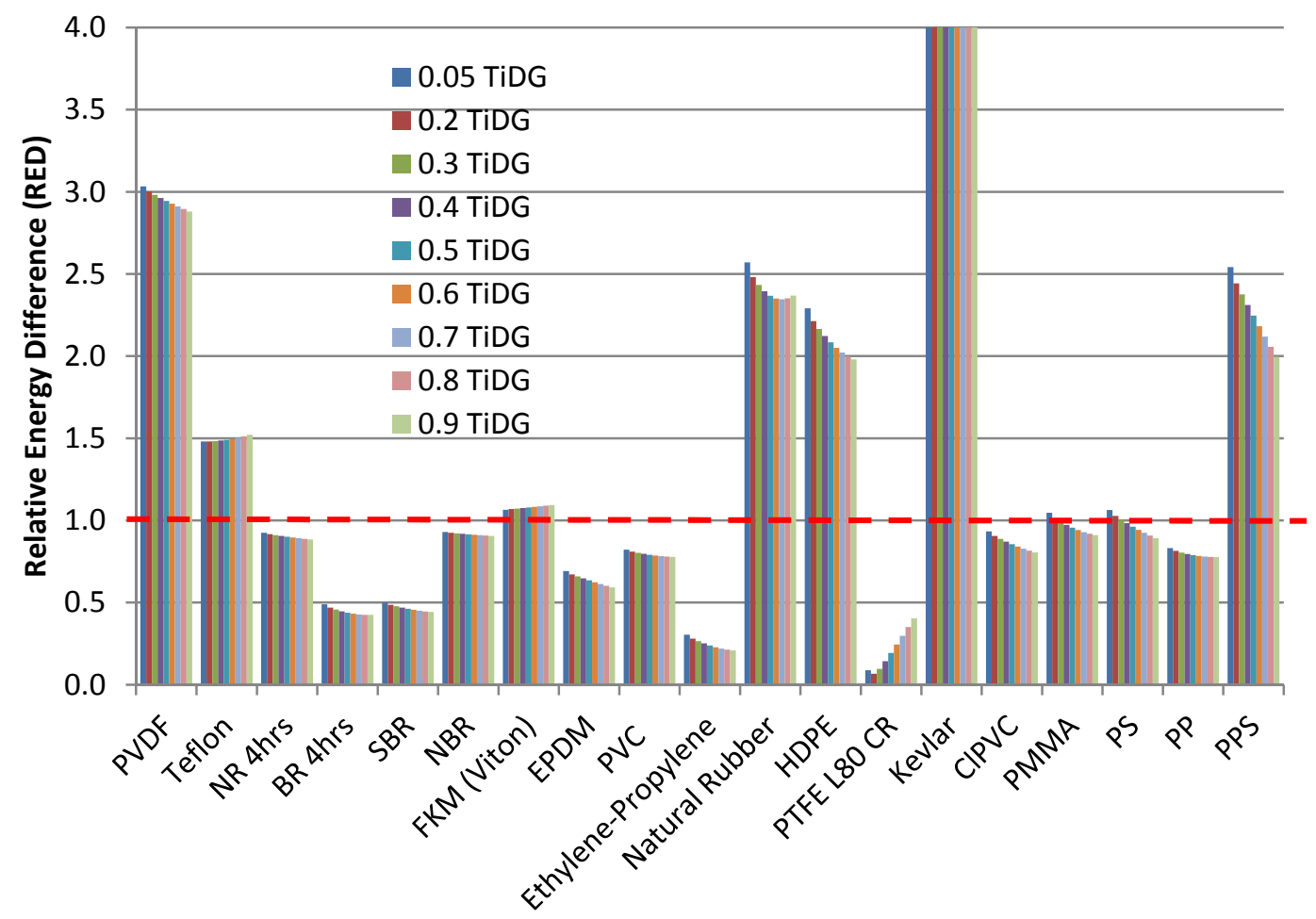

Figure 3-5. The Relative Energy Difference between a TOA-TiDG mixture and the polymers and elastomers examined in this work.

There are other factors that affect swelling of polymers that include crosslink density, crystallinity, and molecular weight. High percentage or concentration or quantities of these structural or chemical parameters reduce the impact of the suppressors. Furthermore, the sorption kinetics of the suppressor will be significantly impeded by the size of these suppressors. TOA has a molar size of $434 \mathrm{~cm}^{3} / \mathrm{mol}$ while LIX $® 79$ and TiDG have 402 and $518 \mathrm{~cm}^{3} / \mathrm{mol}$, respectively. In addition, the suppressor geometry (a comb like structure) is not ideal for solvent reptation inside the polymer. Thus, sorption and diffusion will be very slow for the new suppressors. And once the suppressor is inside a rubber material, it must have the sufficient energy to break the intermolecular bonds (or C-S-C or sulfur bonds for example) for maximum mixing and interaction. In the case of hydrogen bonded materials like Kevlar ${ }^{\circledR}$ aromatic polyamide (see Fig. 3-6), the suppressor must overcome the strong intermolecular hydrogen bonding between the aramid fibers and break the crystallinity of these fibers. This is a very slow process if not unlikely.

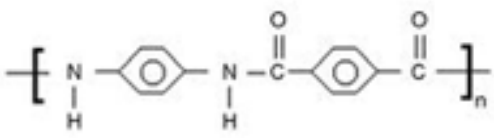

Figure 3-6 A schematic of $\operatorname{Kevlar}^{\circledR}$ aromatic polyamide chemical structure

On the other hand, the new suppressor (TiDG) may interact favorably with Vellumoid since it is composed of protein and glycerin that can readily interact with the amine groups in TiDG. Therefore, material leaching from Vellumoid into the NGS solvent is expected where this material is used in contact. Since Vellumoid is used at the mixer in Saltstone where small concentrations of solvent may contact it, 
the leaching extent and leaching rate will be minimal. If current performance has been acceptable, this material should still perform adequately.

Since polymeric components are often used in confined spaces (such as O-rings or gaskets within grooves or between flanges), the expected infiltration, swollen, gel, and liquid layers that typically form in a polymer attacked by a suitable solvent may not be possible or should at least be minimized. In the case of a gasket between flanges, only the inner edges will likely be exposed, minimizing degradation rate and solvent effects (material release into the process aside). Therefore, with the exception of Vellumoid, the new suppressor (TiDG) is not expected to significantly affect or impact the polymers known to be used in DWPF and Saltstone facilities.

In Saltstone, the concentration of NGS in the grout and in the bleedwater is expected to be small. Therefore, the potential for and magnitude of effects on polymers specifically used in the Saltstone process (such as polypropylene sheet drain fabric or thermosetting linings linings used in the Saltstone Disposal Units or SDUs) are expected to be low. Mostly, the low free volume and polarity of thermoset polymers limits the adsorption capability of NGS.

\section{MaxCalix}

Another component of the improved solvent that can interact with the polymers studied here is MaxCalix. Figure 3-7 shows the RED interaction values between MaxCalix and the polymers investigated. As can be seen from Fig. 3-7, the RED numbers are much larger than the value of one. Thus, it is expected that no significant interaction will occur between MaxCalix and the existing polymers used at DWPF, Saltstone, and MCU. BOBcalix is slightly smaller than MaxCalix (302 versus $364 \mathrm{~cm}^{3} / \mathrm{mol}$ ) but it has a larger solubility parameter (61.9 versus $46.1 \mathrm{MPa}^{1 / 2}$ ). Thus, BOBCalix is expected to have no significant interactions with the polymers studied here.

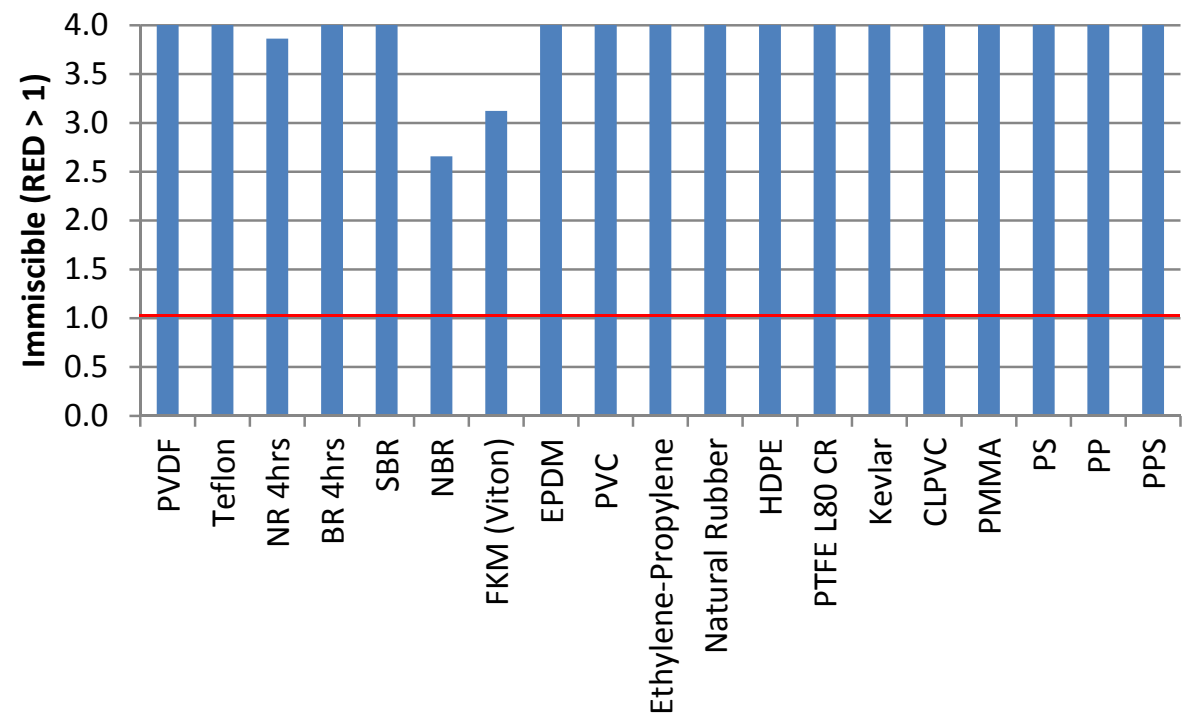

Figure 3-7. The Relative Energy Difference (RED) between MaxCalix and the elastomers and thermoplastics under consideration.

$\underline{\text { Isopar }^{\circledR} \mathrm{L}}$

Isopar ${ }^{2} \mathrm{~L}$ is a smaller molecule than MaxCalix (196 versus $364 \mathrm{~cm}^{3} / \mathrm{mol}$ respectively) and it could interact more readily with the polymers currently used at DWPF and Saltstone. 
Isopar ${ }^{\circledR} \mathrm{L}$ is composed of branched and linear hydrocarbons atoms ranging from 10 to 14 carbon atoms. The miscibility impact of Isopar ${ }^{\circledR} L$ is bounded by the chemical activity of its lower molecular weight component such as decane $\left(\mathrm{C}_{10} \mathrm{H}_{23}\right)$. Decane is typically used as a plasticizer for commercial polymer (often a diluent for tributyl phosphate). The computed RED interaction values for decane are shown in Figure 3-8. Figure 3-8 shows an attractive interaction with polypropylene, ethylene-propylene, ethylenepropylene-diene, butadiene, and styrene-butadiene rubber. These polymers have a high dispersion force comparable to that of decane.

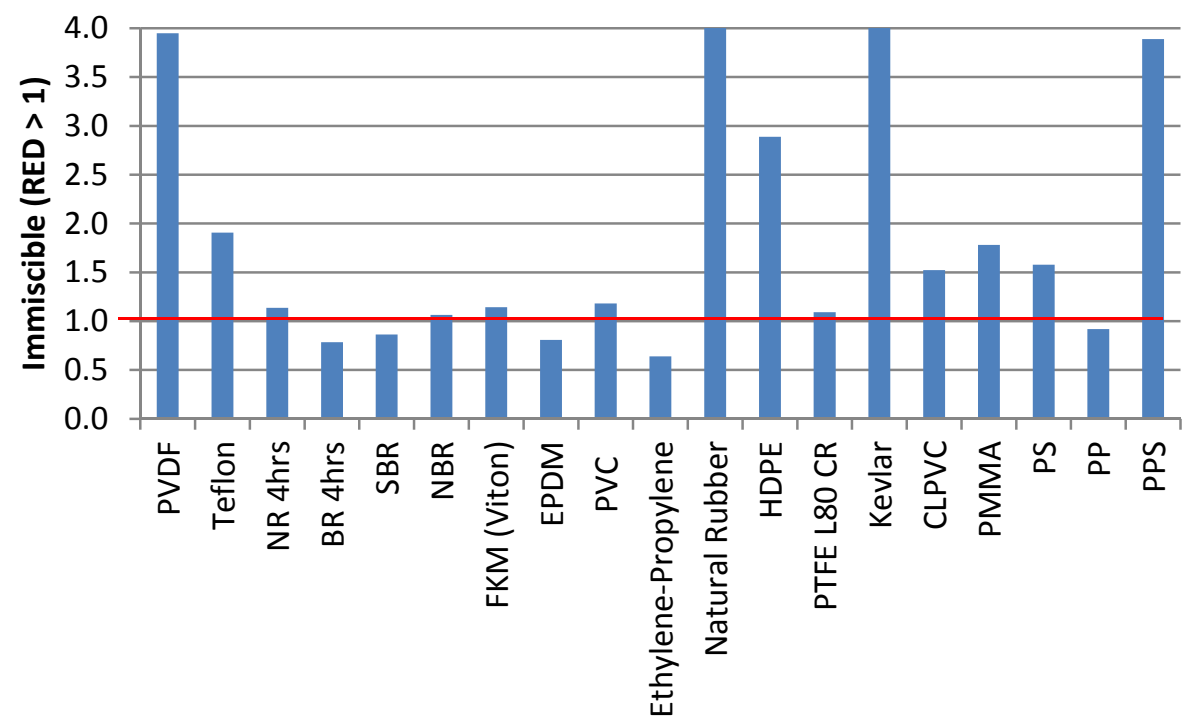

Figure 3-8. The Relative Energy Difference (RED) between Isopar ${ }^{\circledR} \mathrm{L}$ and the polymers under consideration

The expected swelling for the polypropylene and ethylene containing polymers is below $10 \%$ of the maximum swelling these polymers can experience. Fig. 3-9 shows an attractive interaction between polymers containing ethylene and propylene molecular units and decane.

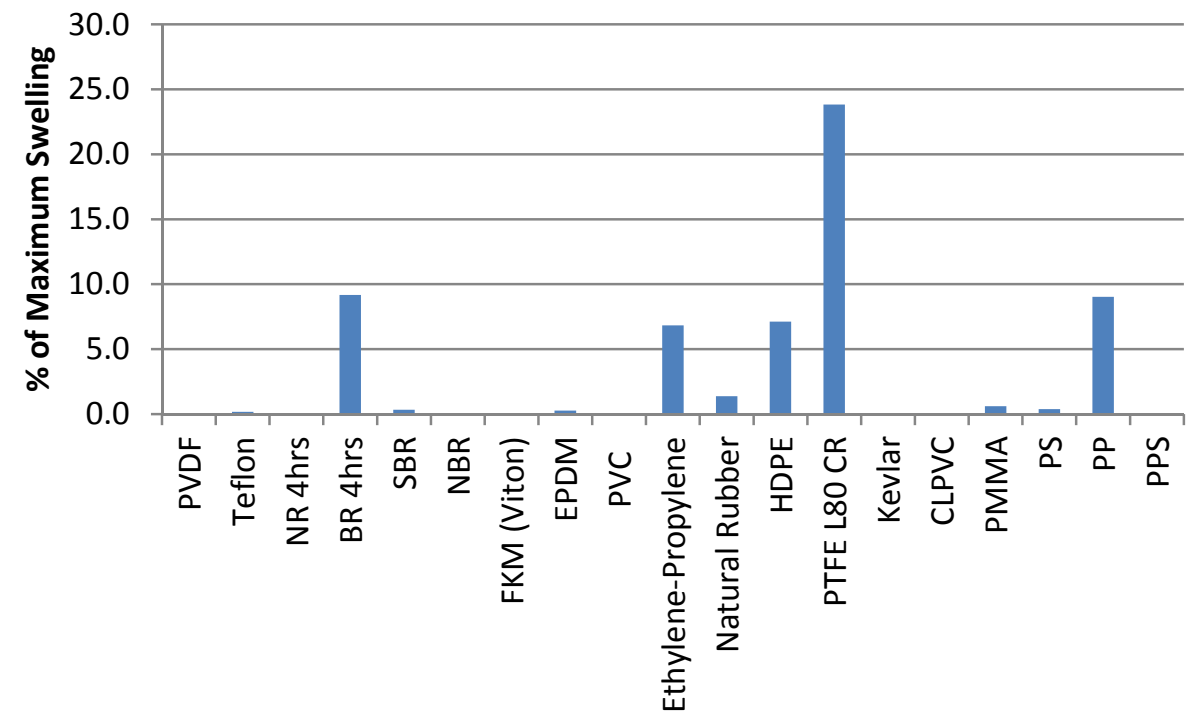

Figure 3-9. The percent of maximum swelling expected for these polymers in contact with dodecane. 


\section{Radiation and Temperature Effects}

During service, these polymers will receive alpha, beta, and gamma irradiation. The most penetrating, prevalent, and harmful of these is gamma irradiation. Polymer exposure to gamma irradiation leads to radical formation that attacks and unzips the backbone of polymer chains. In rubber, an increase in crosslinked density can lead to embrittleness as well as the formation of cyclic compounds is often observed. Please note that different effects may observed at different dose rates for example, different rates of chain scission versus crosslinking. Gamma radiation tends to increase the dipolar and hydrogen bonging forces of polymers with the introduction of oxygen-containing species into the polymer. Since these polymers and elastomers have negligible interaction with the NGS, they will age at the same rate under gamma irradiation (at the same dose) as if there were not in contact with NGS. The extent of polymer damage needed to change the polymer solubility to interact with NGS is significantly large and at that point the polymer will unlikely be unable to perform its function regardless.

Increasing temperature is known to increase miscibility and permeability of organic liquids into polymers. The effect of temperature on the HSP of polymers and elastomers is via their thermal expansion coefficient as shown in Eq. 5, Eq. 6, and Eq. 7 where temperature is given in ${ }^{\circ} \mathrm{C}^{7}$

$\frac{d \delta_{d}}{\delta_{d}}=-1.25 \times \alpha \times d T$

$\frac{d \delta_{p}}{\delta_{p}}=-0.5 \times \alpha \times d T$

$\frac{d \delta_{H}}{\delta_{H}}=-(1.22 E-3+0.5 \times \alpha) d T$
Equation 5

Equation 6

Equation 7

The thermal expansion of polymers and elastomers ranges from 30 to $300 \mathrm{E}-6 \mathrm{~mm} / \mathrm{mm} /{ }^{\circ} \mathrm{C}$. Using the highest number (characteristic of elastomers) and $10{ }^{\circ} \mathrm{C}$ temperature change (from $25^{\circ} \mathrm{C}$ to $35^{\circ} \mathrm{C}$ ), the fractional changes of the HSP parameters are $-0.0038,-0.0015$, and -0.01 for the dispersion, dipolar, and hydrogen bonding solubility parameters. These changes are miniscule against the values listed in Table 2-4 and they will not change the conclusions made at room temperature.

\subsection{Conclusions}

An assessment of the dimensional stability of polymers present in MCU, DWPF, and Saltstone facilities (i.e. Grafoil $^{\circledR}$, Tefzel ${ }^{\circledR}$, Isolast ${ }^{\circledR}$, EPDM, NBR, SBR, UHMWPE, and FKM) in the NGS showed that TiDG could selectively affect NBR but the use of this particular elastomer in a confined geometry will likely prevent the NGS from significantly affecting performance. Some degree of swelling is usually acceptable in most components, depending on function. Other polymers like NBR and EPDM were found to interact mildly with NGS but their calculated swelling and the confined geometry will minimize interaction with NGS. Please note that the degree of swelling likely to occur will depend on polymer type as well as the nature of exposure (surface area, confined geometry, etc.). The same polymer might be affected differently in two different applications, even if exposed to the same solvent. In both cases, the polymer will likely maintain functionality. Some applications have zero tolerance for dimensional changes such as the operation of valves while other applications a finite dimensional change improves the function of the application such as seals and gaskets. Additional considerations are required before using the conclusions from this work to judge outcomes in field applications.

Decane, a component of Isopar®L that is most likely to interact with the polymers, mildly interacted with the elastomers and the propylene based polymers but their degree of swelling is at most $10 \%$ and the 
confined geometry that they are typically placed in indicate this is not significant. In addition, it was found that Vellumoid may leach protein into the NGS solvent. Since Vellumoid is used at the mixer in Saltstone where it sees minimum quantities of solvent, this leaching has no effect on the extraction process at MCU or the immobilization process at Saltstone.

No significant interaction is expected between MaxCalix and the polymers and elastomers used at MCU, DWPF, and Saltstone. Overall, minimal and insignificant interactions are expected on extraction and immobilization operations when MCU switches from CSSX to NGS solvent.

It was found that contacting NGS, the polymers and elastomers will age at the same rate under radiation or heat as if there was not solvent at all. No synergistic effects are anticipated.

SRNL recommends the use the HSP method to screen and evaluate the impact of other organics such as alcohols, glycolate, and their byproducts on the polymers used throughout the site. Testing is also recommended whenever is possible to validate the use of this method, as the interactions between as processed, end-use polymer components and various organic compounds may not be accurately predicted by the use of solubility parameters alones. 


\subsection{References}

1 B. Moyer, J. F. Birdwell, L. H. Delmau, D. L. Schuh, E. L. Stoner, N. J. Williams, S. D. Fink, T. B. Peters, R. A. Pierce, R. A. Leonard, and M. W. Geeting, "Next Generation Cesium Solvent”, EM Technical Exchange Meeting, Atlanta, GA, Nov. 16-18, 2010.

2 B. A. Moyer, P. V. Bonnesen, L. H. Delmau, F. V. Sloop, Jr., N. J. Williams, J. F. Birdwell, Jr., D. L. Lee, R.A. Leonard, S. D. Fink, T. B. Peters, and M. W. Geeting, "Development of the Next-Generation Caustic-Side Solvent Extraction (NG-CSSX) Process for Cesium Removal from High-Level Tank Waste”, WM2011 Conference, February 27-March 3, 2011 (Phoenix, AZ).

3 T. B. Peters, S. D. Fink, "Results of the First Extraction-Scrub-Strip Testing Using Improved Solvent Formulations”, SRNL-STI-2010-00586, Rev 0, September 2010.

4 T. B. Nielsen and C. M. Hansen, "Elastomer Swelling and Hansen Solubility Parameters", Polymer Testing 24(2005), 1054-1061.

5 F. F. Fondeur, T. B. Peters, and S. D. Fink, "Next Generation Solvent - Materials Compatibility with Polymer Components within Modular Caustic-Side Solvent Extraction Unit,” SRNL-STI-2011-0199, March 31, 2011.

6 F. F. Fondeur, T. B. Peters, and S. D. Fink, "Next Generation Solvent-Material Compatibility with Polymer Components within Modular Caustic-Side Solvent Extraction”, SRNL-STI-2011-00575, September 2011.

7 C. M. Hansen, "Hansen Solubility Parameters: A User Handbook”, CRC press, Boca Raton FL, 1983.

8 A.F.M. Barton, "Handbook of Solubility Parameters and other Cohesion Parameters", 2nd Ed., CRC Press, Boca Raton (1983) 
Appendix A: List of polymers identified to be evaluated for interaction with the improved solvent formulation.

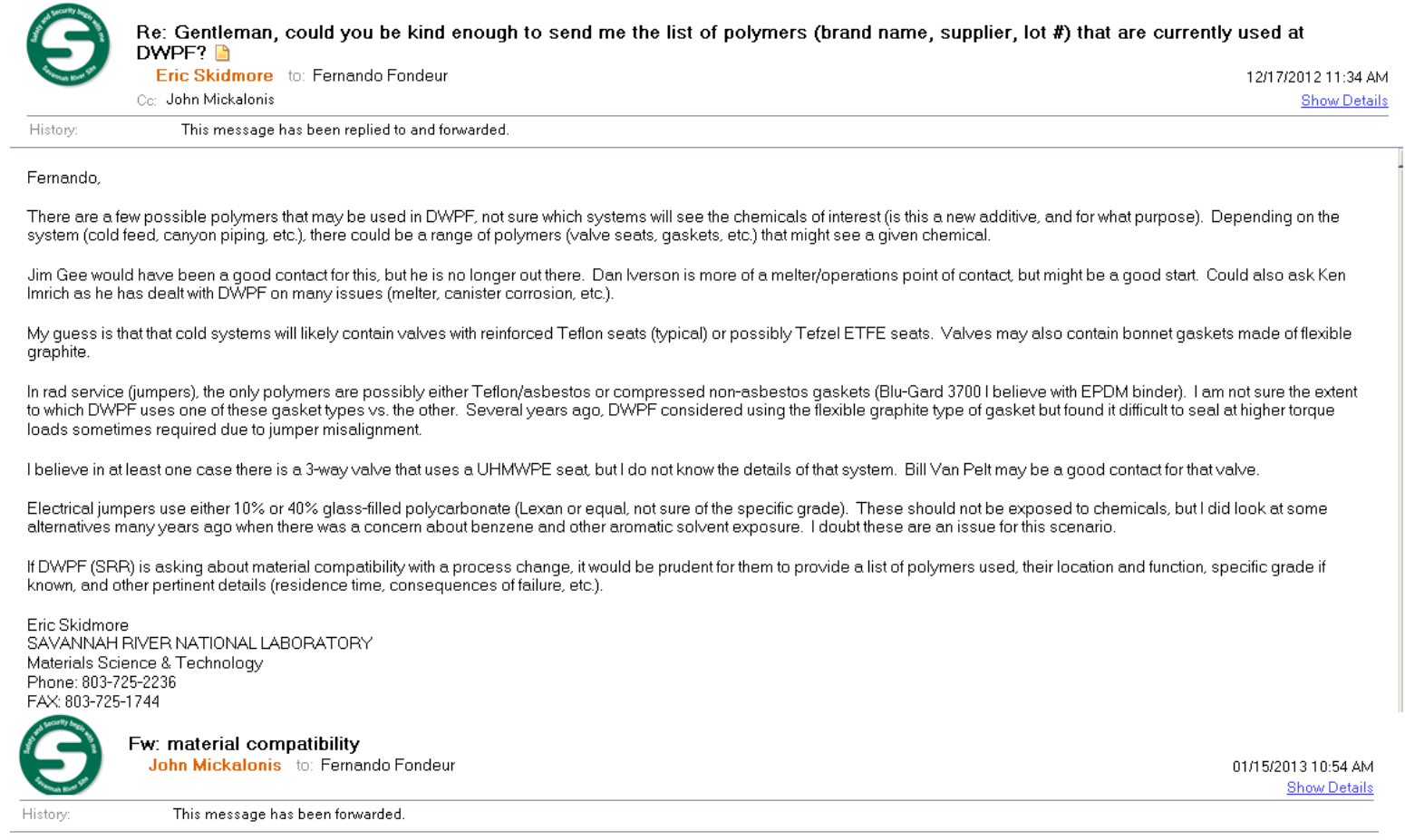

Fernando,

I think that this is what you are looking for.

Have a great day!

John Mickalonis

Savannah River Nuclear Solutions

Savannah River National Laboratory

ldg 773-A. D1124

Aiken, SC 29808

telephone: (803) 725-3292

fax: (803) $725-7369$

email: john.mickalonis@sml.doe.gov 
- The SE transfer lines from MCU are 3 inch schedule 40 304L stainless steel per pipe code P224A. The same pipe code will apply from SWPF.

- When the SE enters the Vit building, it is conveyed by a string of jumpers to the SEFT. They are built to pipe code. P-239 which is 3 inch schedule $40304 \mathrm{~L}$ stainless steel.

- The SEFT vessel is Hastellox C-276

- The SEFT agitator is Hastellox C-276

- The SEFT sample and transfer pumps are Hastellox C-276

- The first transfer jumper from the SEFT to the SRAT is 3/4" schedule $40304 \mathrm{~L}$ stainless steel built to code P-239. It has a $3 / 4^{\prime \prime}$ three-way valve that is made of $316 \mathrm{~L}$ stainless steel. It has an Ultra High Molecular Weight Polyethylene sleeve and packing.

- The rack jumpers in the Christmas tree are $3 / 4$ " schedule 40 Hastellox C-276 built to pipe code P213.

- The Christmas tree racks themselves are $3 / 4$ " schedule 40 Hastellox $\mathrm{C}-276$ built to pipe code P213.

- The final transfer jumper is $3 / 4$ " schedule 40 Hastellox $\mathrm{C}-276$ built to pipe code P-213.

- The SRAT itself is Hastellox C-276.

- The jumper has gaskets that are Teflon impregnated asbestos cloth with stainless steel wires imbedded. The reference drawing is P-PJ-H-7939 Rev. 18.

- The pumps have Grafoil (sheet graphite material) gaskets and Viton A O-rings.

Saltstone Materials List for compability with NGS
Katie-Dara Dixon to: Fernando Fondeur
Co: Earl Brass, Michael Potvin. David Herman, Thomas Peters, Aaron Staub, Azadeh Samadi-Dezfouli, Annah Garrison

Fernando,

Below are the gaskets materials at Saltstone that are not already covered in what DWPF sent to you. Please include the following gasket material in your write-up for material capability regarding NGS. Testing is not needed, SME judgement is sufficient to review these gasket materials and make a statement about the compatibility.

Thanks,

Dara Dixon

8-7157

Non-Metallic

NBR Inorganic fiber

NBR Bonded Kevl

Grade TNitrile

EPDM/Aramid Fiber

Graphite

EPDM

Vellumoid

PTFE

SBR/Synthetic Fiber

Metallic

Spiral Wound w/Graphite Fille

Spiral wound w/Teflon Filler 
Appendix B: Plasticizers commonly used with polymers and rubbers.

\begin{tabular}{|l|}
\hline Dodecane 228.5 \\
\hline Diethyl malonate 151.8 \\
\hline Diethyl oxalate 135.4 \\
\hline Dioctyl adipate 399 \\
\hline Tributyl acetylcitrate 384 \\
\hline Dimethyl phthalate 163 \\
\hline Diethyl phthalate 198 \\
\hline Dibutyl phthalate 266 \\
\hline Dioctyl phthalate 377 \\
\hline Benzyl butyl phthalate 335 \\
\hline Trimethyl phosphate 116.7 \\
\hline Triethyl phosphate 169.7 \\
\hline Tricresyl phosphate 316 \\
\hline Dodecane 228.5 \\
\hline Diethyl malonate 151.8 \\
\hline Diethyl oxalate 135.4 \\
\hline Dioctyl adipate 399 \\
\hline Trioctyl phosphate 469 \\
\hline Transformer oil 300 \\
\hline Nitrile of oleic acid \\
\hline
\end{tabular}

\section{Inorganic fillers}

Black soot HAF N330 or FEF N550 or EPC S300

Aluminosilicate (Kaolin)

Calciumsilicate (wollastonite)

Magnesium silicate (talc)

Aluminum/potassium silicate (mica)

Magnesium silicate (asbestos)

Hydrated aluminum oxide

Antimonium oxide

Magnesium oxide

Titanium oxide

Zinc oxide

Silicon dioxide (precipitated or diatomecious earth)

Calcium carbonate

Barium carbonate

Magnesium carbonate

Barium sulfate

Calcium sulfate

Grounded metals of bronze, aluminum, lead and zinc

Molybdenum disulfate

Glass

Accelerators, activators, inhibitors, fillers, antioxidant, antiozone, lubricant, processing, pigments,

Stearic acid, sulfur, bromotiazol mercaptan disulfur, ciclohexyl benzothiasol sulfamide, tetramethyl tiuramide.zinc diethyl dicarbamate, 